\title{
The Perceived Value of Airline Flight Operations Internship Activities and/or Benefits in the Pursuit of Career Goals
}

\author{
Jose' R. Ruiz \\ Southern Illinois University
}

\begin{abstract}
Collegiate aviation institutions throughout the United States have been involved in airline flight operations internship programs for over 20 years. Collegiate aviation and industry partnerships serve a variety of purposes, including: (a) allowing a student the opportunity to observe and experience the many facets of a commercial air carrier operation, (b) developing a greater awareness of the airline industry for the student, allowing for better-informed career choices and, (c) providing the airline with access to a low-cost, highly qualified, temporary workforce and a potential employee pool. This graduate follow-up study involved students who participated in the Southern Illinois University Carbondale (SIUC) Aviation Management and Flight (AVMAF) airline flight operations internship program. The study examined data gathered from students who served as interns at one of six different U.S. major air carriers and one U.S. regional air carrier. Former interns were asked to rate the value 14 specific internship activities/benefits had in the pursuit of their career goals. Former interns were also allowed the opportunity to identify other valuable internship activities and/or benefits not originally mentioned in the survey via open-ended response. Respondent employment demographic data are reported. The most valuable and least valuable internship activities and/or benefits identified by the collective group are reported. The most valuable and least valuable internship activities and/or benefits identified for each airline are reported. Recommendations for improving airline flight operations internship programs are also provided.
\end{abstract}

\section{INTRODUCTION}

Collegiate aviation institutions throughout the United States have been involved in airline flight operations internship programs for over 20 years (NewMyer, Ruiz \& Rogers, 2000).

Collegiate aviation and industry partnerships serve a variety of purposes, including: (a) allowing an intern the opportunity to observe and experience the many facets of a commercial air carrier operation, (b) developing a greater awareness of the airline industry for the intern, allowing for better-informed career choices, and (c) providing access to a low-cost, highly qualified, temporary workforce and a potential employee pool.

Employers gain access to committed, knowledgeable, temporary, and low-cost help, plus an opportunity to groom potential full-time employees. The participating students get a unique opportunity to experience the real world in their chosen profession. Co-op programs usually provide pay and/or academic credit, and the participants gain a "foot in the door" with a familiar post-graduate employment prospect. (Kiteley, 1997, p. 1)

Recognizing the potential benefits associated with these industry partnerships, many collegiate aviation programs throughout the country maintain internship agreements with at least one U.S. domestic air carrier. "According to the University Aviation Association, students can choose [an airline flight operations internship] from among more than 270 two- or four-year accredited aviation colleges or universities” (Phillips, 1996, p. 43).

At the time of this research study, the Aviation Management and Flight (AVMAF) Department at Southern Illinois University Carbondale (SIUC) offered airline flight operations internships with six major air carriers and one regional carrier. During the course of an airline flight operations internship, a variety of activities and/or benefits are made available to interns by the participating airline. This study identified 14 internship activities and/or benefits offered by at least one of the seven participating 
airline partners. How valuable are these activities and/or benefits in the pursuit of career goals? The "most valuable" and "least valuable" internship activities and/or benefits, as perceived by former interns, are identified and categorized by airline. A collective analysis was also conducted. Recommendations designed to improve airline flight operations internship programs and promote future study are also provided.

\section{AIRLINE FLIGHT OPERATIONS INTERNSHIPS}

Airline flight operations internship programs provide students the opportunity to experience the airline environment for a pre-determined period of time (typically one academic semester) at an off-campus location for academic credit. Qualifications vary, but many airline flight operations internship programs require students to possess at least a private pilot certificate. While on the internship, students are expected to perform a variety of administrative support functions. However, interns are also exposed to the varied operational and support functions associated with an airline.

Phillips (1996) discussed airline internship programs at United, Delta, TWA, USAir, and FEDEX. The article mentioned numerous benefits associated with these internships, including: (a) full-time employment at United and FEDEX, (b) potential for being hired at Delta, (c) aircraft simulator time, (d) travel benefits, and (e) jump seat flights or Additional Crewmember (ACM) privileges.

Simply stated, an internship or cooperative education program (co-op) is an opportunity for a college student to combine traditional on-campus academic learning with professional work experience in a chosen field. These programs allow students in a large number of collegiate aviation programs to bridge the gap between the classroom and the real world. (p. 44)

D. Parker (personal communications, March 8, 2002), United Parcel Service (UPS) 727 Ground School Supervisor felt that the internship program was valuable for both the student and the airline.

We have the opportunity to work with the brightest students in [collegiate] aviation. Our interns are trained and qualified to develop sophisticated training aids. We invest quite a bit of money in our interns, but we receive a great return on our investment. We may not guarantee our interns an interview like other airline do, but if an intern does a good job for me - when he's ready, I will personally go to Human Resources and tell them that we need to interview this guy! Now that's an advantage toward achieving your career goals!

B. Davis (personal communications, March 8, 2002), Pilot Recruiter for TWA was enthusiastic in her opinion related to the value of the internship program at TWA.

An internship allows a student the opportunity to observe and participate in activities involved in running an airline getting an airplane off the ground is only one facet of the operation. Classroom instruction is great, but an internship allows a student to apply his knowledge. An internship can pay off big dividends as a student applies for employment in the future. We consider an internship to be a four-month interview. If an intern applies for a job at TWA, we know what we're getting and they [the intern] know what they're getting into. An internship can really increase your chances of getting a job with an airline.

NewMyer (1991), reported that three airlines: United, Northwest and Eastern had a total of six university or community college "partners" including three airline-university intern agreements. It was noted that these partnerships were a response to "...the airline industry's search for an answer to the need for qualified, quality pilots...” (p. 16).

In a presentation that addressed airline flight operations internship benefits conducted at Concordia University, Ruiz (2001) quoted a statement made by the United Airlines flight 
operations internship program director at that time: "Internships are a phenomenal opportunity for a job interview. Interns are not competing with the other 9000 applicants - they can move into the flight deck five years earlier than noninterns, resulting in an additional \$7 - \$7.5 million in career earnings.” (p.22)

\section{SOUTHERN ILLINOIS UNIVERSITY CARBONDALE}

The Aviation Management and Flight Department of Southern Illinois University Carbondale has administered an airline flight operations internship program since 1987. At the time of this study, the SIUC AVMAF department maintained formal airline flight operations internship agreements with six U.S. major domestic air carriers, including: American Airlines, Delta Air Lines, Northwest Airlines, Trans World Airlines LLC, United Airlines and United Parcel Service. A formal airline flight operations internship agreement also existed between the SIUC AVMAF department and Chicago Express Airlines, a U.S. regional carrier serving the Midwest. Each of these air carriers expose interns to a variety of activities and/or benefits for participating in the internship.

\section{PURPOSE OF THE STUDY}

The purpose of this study was to identify what value former interns assigned to multiple airlines placed on individual airline flight operations internship activities and/or benefits in the pursuit of career goals. This report is intended to assist airline flight operations internship program managers develop an internship program that will emphasize learning experiences former interns perceived as valuable in the pursuit of career goals.

\section{Methodology}

The population for this study included SIUC AVMAF students who completed airline flight operations internships with U.S. air carriers that maintained a formal airline flight operations internship agreement with SIUC. The SIUC AVMAF department and airline internship partners performed a records review and identified 224 students who met the population criteria from July 1987 through May 2002. Twenty-three airline flight operations interns had served with American Airlines, 9 with Chicago Express Airlines, 20 with Delta Air Lines, 8 with Northwest Airlines, 23 with Trans World Airlines, 136 with United Airlines, and 13 with United Parcel Service. Eight interns served on multiple (two) internships.

A total of 218 intern addresses were obtained from the SIUC Alumni Association and SIUC AVMAF internship records. Addresses for six former interns who served at United Airlines were not available. A total of 226 survey questionnaires were mailed to 218 former interns. Eight of the former interns attended multiple (two) internships and, therefore, received two questionnaires, accounting for a total of 226. Two mailings of the survey questionnaire were conducted over a three month period. The first and second mailings of the survey questionnaire resulted in the receipt of 150 survey questionnaire responses, a response rate of 66.4 percent.

\section{SURVEY QUESTIONNAIRE}

The survey questionnaire made use of a linear, numeric scale-based opinionnaire to elicit the perceived value of 14 airline flight operations internship activities and/or benefits in the pursuit of career goals (see Table 1). SIUC AVMAF internship program records indicated that each internship activity and/or benefit listed in the survey questionnaire was offered by at least one of SIUC's seven airline partners. Scale values ranged from "Extremely Valuable" $=5$ to "No Value" = 1 . The survey questionnaire also contained an open-ended section that allowed respondents to identify additional internship activities and/or benefits they considered valuable. 
Table 1. Airline Flight Operations Internship Activities and/or Benefits

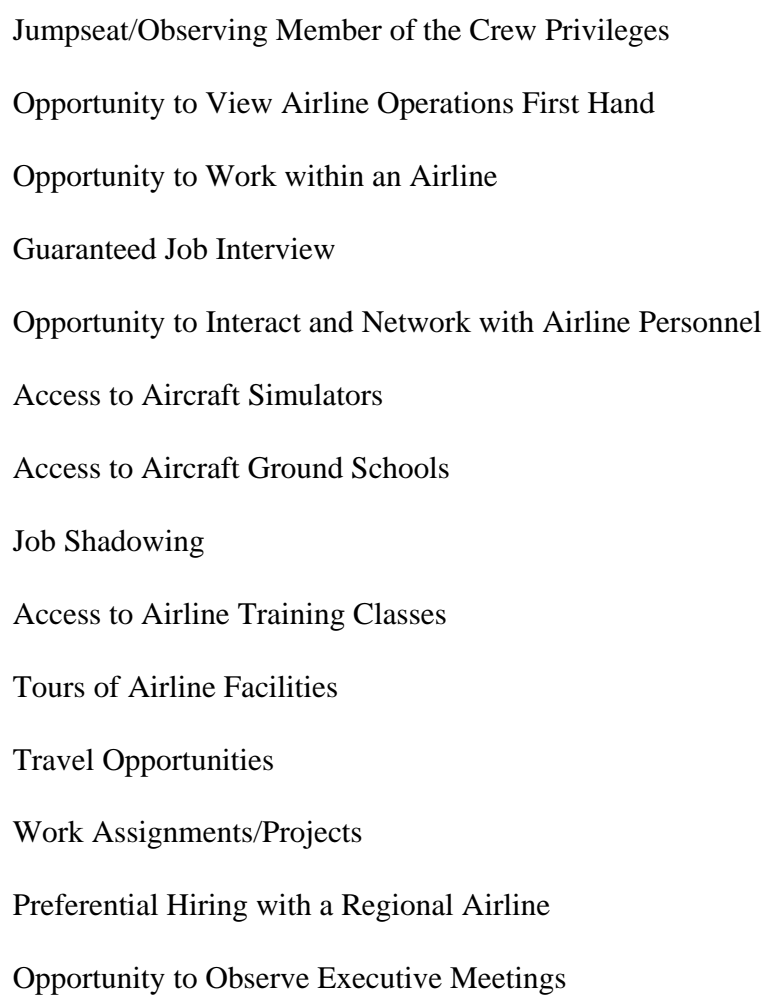

\section{Analysis}

Data collected from the survey questionnaire was described using Statistical Product and Service Solutions (SPSS) generated means, standard deviations, frequencies and percentages. When comparing airlines, Chisquare tests were conducted and cross-tabulation tables were examined to identify statistically significant differences in responses at the $p<.05$ level. "In psychological and educational circles, the 5 percent (.05) level of significance is often used as the standard for rejection" (Best, J.W. \& Kahn, J.V., 1993). A Kruskal-Wallis test was conducted on activities and/or benefits identified as statistically significant by the Chi-square test to confirm findings.

\section{RESPONDENT EMPLOYMENT DATA}

One hundred forty-four respondents (96\%) indicated that they were employed in aviation professions. Six respondents (4\%) indicated that they were employed in non-aviation professions.
One hundred thirty-seven respondents (91\%) reported that they were employed as pilots by a major airline, a regional airline, a corporate entity, the military, or a flight school (see Table 2). In several cases, respondents indicated that they were employed by two organizations, e.g., full-time employment with a major airline and part-time employment with the Air National Guard, thus explaining why 137 pilots reported occupying 147 positions. Regional airlines employed the majority of respondents (36.7\%). Respondents who interned with Chicago Express Airlines, the only regional airline in this study, were all employed by Chicago Express (100\%). The military employed the fewest number of respondents (2.8\%). 
Table 2. Pilot Positions Presently Occupied by Respondents

\begin{tabular}{lcc}
\hline \multicolumn{1}{c}{ Employer } & Frequency & Percentage \\
\hline Regional Airline & 54 & 36.7 \\
Major Airline & 49 & 33.3 \\
Flight & 26 & 17.7 \\
Instruction & 14 & 9.5 \\
Corporate & 4 & 2.8 \\
Military & 147 & 100 \\
Total & & \\
\hline
\end{tabular}

United Airlines employed 37 of the 49 respondents (75.5\%) flying for a major airline (see Table 3). Collectively, other participating major air carriers employed 12 respondents (24.4\%). Of the 37 respondents hired as pilots by United, 36 of the respondents (97.2\%) interned with United. Of the remaining 12 respondents hired as pilots by various other major airlines, 1 interned with UPS, 2 interned with TWA, 3 interned with Delta, and 6 interned with United.

Table 3. .Major Airlines that Employ Respondents

\begin{tabular}{lcc}
\hline Employer & Frequency & Percentage \\
\hline United & 37 & 75.5 \\
American & 4 & 8.1 \\
Delta & 3 & 6.2 \\
UPS & 3 & 6.2 \\
US & 1 & 2.0 \\
Airways & 1 & 2.0 \\
FEDEX & 1 & 100 \\
Total & 49 &
\end{tabular}

\section{FINDINGS}

\section{Collective Ranking of Activities and/or Benefits}

Respondents identified "Jumpseat/ Observing Member of the Crew Privileges” as the most valuable internship activity and/or benefit in the pursuit of career goals $(M=4.55)$.
This activity and/or benefit also had one of the smallest standard deviations in this section of the survey questionnaire $(S D=.76)$. This standard deviation indicates that responses related to the perceived value of this activity and/or benefit was similar (see Table 4). Notably, 137 respondents (91.3\%) rated the "Jumpseat/Observing Member of the Crew Privileges" activity and/or benefit to be "Valuable" or "Extremely Valuable" in the pursuit of career goals.

Respondents also indicated that several other activities and/or benefits were highly valued. "Opportunity to View Airline Operations First Hand" $(M=4.50)$, "Opportunity to Work within an Airline" ( $M=$ 4.48), "Opportunity to Interact and Network with Airline Personnel” ( $M=4.37)$, “Access to Airline Simulators" $(M=4.09)$, and "Access to Aircraft Ground Schools $(M=4.04)$ were internship activities and/or benefits that ranged between "Valuable" and "Extremely Valuable" in the pursuit of career goals (see Table 4). The standard deviation associated with these five activities and/or benefits were among the lowest in this section of the survey questionnaire $(S D=$ $.69, .74, .73,1.08$ and 1.07, respectively), suggesting that responses related to the perceived value of these activities and/or benefits were not widely dispersed. The internship activity and/or benefit "Guaranteed Job Interview" received a high rating $(M=$ 4.41), but it also received the second highest standard deviation in this section $(S D=1.14)$. This indicates that responses related to the perceived value of this activity and/or benefit varied more than responses to other activities and/or benefits (see Table 4).

Respondents identified "Opportunity to Observe Executive Meetings" as the least valuable internship activity and/or benefit in the pursuit of career goals $(M=3.52)$. This activity and/or benefit also had the fourth highest standard deviation in this section of the survey questionnaire $(S D=1.11)$.

The "Preferential Hiring with a Regional Airline" internship activity and/or benefit received the second lowest rating in this section $(M=3.65)$. It also had the highest standard deviation in this section of the survey questionnaire $(S D=1.50)$. However, almost half 
of the respondents $(40.7 \%)$ reported that the "Preferential Hiring with a Regional Airline" internship activity and/or benefit were not available to them at the time of their internship. Of the 89 respondents that did have access to the "Preferential Hiring with a Regional Airline" internship activity and/or benefit, 51 respondents (57.3\%) rated it as "Valuable" or "Extremely Valuable" in the pursuit of career goals. Respondents perceived the remaining internship activities and/or benefits as less valuable in the pursuit of career goals (see Table 4). Means for these activities and/or benefits ranged from 3.65 to 3.95 on a five point scale.

Respondents identified six additional internship activities and/or benefits they considered valuable in an open-ended section of the survey questionnaire. Narrative responses were organized according to key terms, phrases and prevailing themes (see Table 5).

Table 4. Ranking of Airline Flight Operations Internship Activities and/or Benefits

\begin{tabular}{|c|c|c|}
\hline Activity and/or Benefit Ranking & Mean & $\begin{array}{l}\text { Standard } \\
\text { Deviation }\end{array}$ \\
\hline Jumpseat/Observing Member of the Crew Privileges & 4.55 & .76 \\
\hline Opportunity to View Airline Operations First Hand & 4.50 & .69 \\
\hline Opportunity to Work within an Airline & 4.48 & .74 \\
\hline Guaranteed Job Interview & 4.41 & 1.14 \\
\hline Opportunity to Interact and Network with Airline Personnel & 4.37 & .73 \\
\hline Access to Aircraft Simulators & 4.09 & 1.08 \\
\hline Access to Aircraft Ground Schools & 4.04 & 1.07 \\
\hline Job Shadowing & 3.95 & .95 \\
\hline Access to Airline Training Classes & 3.95 & 1.09 \\
\hline Tours of Airline Facilities & 3.83 & .97 \\
\hline Travel Opportunities & 3.81 & 1.11 \\
\hline Work Assignments/Projects & 3.67 & .96 \\
\hline Preferential Hiring with a Regional Airline & 3.65 & 1.50 \\
\hline Opportunity to Observe Executive Meetings & 3.52 & 1.11 \\
\hline
\end{tabular}

Note. Rankings were based on responses to a 5-point scale ( 1 = No Value, 5 = Extremely Valuable $)$

$\mathrm{N}=150$ 
Table 5. Additional Internship Activities and/or Benefits Identified by Respondents

\begin{tabular}{lcc}
\hline \multicolumn{1}{c}{ Activities and/or Benefits } & Frequency & Percentage \\
\hline Interview Preparation/Access to the Hiring Process & 11 & 29.0 \\
Friendships with Other Interns & 8 & 21.0 \\
Access to Training Materials & 7 & 18.5 \\
Boeing Manufacturing Plant Tour & 5 & 13.0 \\
Flight Engineer Rating & 4 & 10.5 \\
Maintenance Facility Tours & 3 & 8.0 \\
Total & 38 & 100 \\
\hline
\end{tabular}

Note. Responses were to an open-ended section of the survey questionnaire.

\section{MOST VALUABLE AND LEAST VALUABLE ACTIVITIES AND/OR BENEFITS BY AIRLINE}

This section identifies the airline flight operations internship activities and/or benefits considered most valuable and least valuable in the pursuit of career goals by respondents from individual airlines. Means and standard deviations are used to describe data gathered for each item in the survey questionnaire by airline.

\section{American Airlines.}

A total of 18 survey questionnaire responses were received from 23 former American Airlines flight operations interns (78\%). Respondents identified the "Jumpseat/Observing Member of the Crew Privileges" internship activity and/or benefit as the most valuable in the pursuit of career goals $(M=4.56)$. The standard deviation associated with the activity and/or benefit was .86, indicating that responses related to this activity and/or benefit were not widely dispersed.

Respondents identified the "Opportunity to Observe Executive Meetings” internship activity and/or benefit as the least valuable in the pursuit of career goals $(M=3.38)$. The standard deviation associated with this activity and/or benefit was the fourth highest among those provided by respondents from American Airlines $(S D=1.12)$, indicating that responses related to this internship activity and/or benefit varied more than responses for other activities and/or benefits.

\section{Chicago Express Airlines/ATA Connection.}

A total of seven survey questionnaire responses were received from nine former Chicago Express Airlines flight operations interns (78\%). Respondents identified the "Guaranteed Job Interview" and "Preferential Hiring with a Regional Airline” internship activities and/or benefits as the most valuable in the pursuit of career goals. Both internship activities and/or benefits had a mean of 5.00. The standard deviation associated with both activities and/or benefits was .00, indicating that responses related to these activities and/or benefits were exactly alike.

Respondents identified two internship activities and/or benefits as the least valuable in the pursuit of career goals. These activities and/or benefits were "Tours of Airline Facilities" and "Travel Opportunities", both activities and/or benefits had a mean of 3.43. The standard deviation associated with the "Tours of Airline Facilities" activity and/or 
benefit was .79 , indicating that responses related to this internship activity and/or benefit were not widely dispersed. The standard deviation associated with the "Travel Opportunities" activity and/or benefit was 1.27, the second highest reported by respondents from Chicago Express Airlines, indicating that responses related to this internship activity and/or benefit varied more than responses for other activities and/or benefits.

\section{Delta Air Lines}

A total of 18 survey questionnaire responses were received from 20 former Delta Air Lines flight operations interns (90\%). Respondents identified the "Opportunity to Work within an Airline" internship activity and/or benefit as the most valuable in the pursuit of career goals $(M=$ 4.78). The standard deviation associated with the activity and/or benefit was .43 , indicating that responses related to this activity and/or benefit were not widely dispersed.

Respondents identified the "Preferential Hiring with a Regional Airline" internship activity and/or benefit as the least valuable in the pursuit of career goals $(M=3.38)$. The standard deviation associated with this activity and/or benefit was the highest among those provided by respondents from Delta Air Lines $(S D=1.67)$, indicating that responses related to this internship activity and/or benefit varied more than responses for other activities and/or benefits.

\section{Northwest Airlines.}

A total of four survey questionnaire responses were received from eight former Northwest Airlines flight operations interns (50\%). Respondents identified two internship activities and/or benefits as the most valuable in the pursuit of career goals, "Access to Airline Training Classes" $(M=5.00)$ and "Access to Aircraft Ground Schools” $(M=5.00)$. The standard deviation associated with each of these activities and/or benefits was .00, indicating that responses related to these activities and/or benefits were exactly alike.

Respondents identified the "Travel Opportunities” internship activity and/or benefit as the least valuable in the pursuit of career goals $(M=3.25)$. The standard deviation associated with this activity and/or benefit was the highest among those provided by respondents from Northwest Airlines $(S D=$ 1.50), indicating that responses related to these internship activities and/or benefits varied more than responses for other activities and/or benefits.

\section{Trans World Airlines}

A total of 18 survey questionnaire responses were received from 23 former TWA flight operations interns (78\%). Respondents identified the "Jumpseat/Observing Member of the Crew Privileges" internship activity and/or benefit as the most valuable in the pursuit of career goals $(M=4.78)$. The standard deviation associated with the activity and/or benefit was .65, indicating that responses related to this activity and/or benefit were not widely dispersed.

Respondents identified the "Preferential Hiring with a Regional Airline" internship activity and/or benefit as the least valuable in the pursuit of career goals $(M=3.33)$. The standard deviation associated with this activity and/or benefit was the highest among those provided by respondents from TWA $(S D=1.63)$, indicating that responses related to this internship activity and/or benefit varied more than responses for other activities and/or benefits.

\section{United Airlines.}

A total of 80 survey questionnaire responses were received from 130 former United Airlines flight operations interns (62\%). Respondents identified the "Guaranteed Job Interview" internship activity and/or benefit as the most valuable in the pursuit of career goals ( $M=$ 4.75). The standard deviation associated with the activity and/or benefit was .75, indicating that responses related to this activity and/or benefit were not widely dispersed.

Respondents identified the "Opportunity to Observe Executive Meetings” internship activity and/or benefit as the least valuable in the pursuit of career goals $(M=3.33)$. The standard deviation associated with this activity and/or benefit was among the highest among those 
provided by respondents from United Airlines $(S D=1.09)$, indicating that responses related to this internship activity and/or benefit varied more than responses for other activities and/or benefits.

\section{United Parcel Service}

A total of five survey questionnaire responses were received from 13 former UPS flight operations interns (38.5\%). Respondents identified the "Access to Aircraft Simulators" internship activity and/or benefit as the most valuable in the pursuit of career goals $(M=$ 4.80). The standard deviation associated with the activity and/or benefit was .45 , indicating that responses related to this activity and/or benefit were not widely dispersed.

Respondents identified the "Preferential Hiring with a Regional Airline" internship activity and/or benefit as the least valuable in the pursuit of career goals $(M=2.50)$. The standard deviation associated with this activity and/or benefit was the third highest among those provided by respondents from UPS $(S D=.71)$, indicating that responses related to this internship activity and/or benefit were not widely dispersed.

Notably, respondents from Delta, TWA, and UPS identified "Preferential Hiring with a Regional Airline" as the least valuable internship activity and/or benefit in the pursuit of career goals.

\section{STATISTICALLY SIGNIFICANT DIFFERENCES AMONG AIRLINES}

Chi-square tests were conducted and crosstabulation tables were examined to identify statistically significant differences in the manner respondents from different airlines viewed individual airline flight operations internship activities and/or benefits. The "Guaranteed Job Interview" internship activity and/or benefit was the only activity and/or benefit found to be statistically significant at the $p<.05$ level, $\left[\mathrm{X}^{2}\right.$ $(24, \mathrm{~N}=128)=46.12, p=.00]$. However, one of the limitations associated with the Chi-square test is as follows:

If there is an unusually small expected frequency in a cell, chi-square (if applied) might result in an erroneous conclusion. For more than two cells, chi- square should not be used if more than 20 percent of the $f_{e}$ cells have expected frequencies less than 5. (Lind, Marchal \& Mason, 2002, p. 559)

According to this rule, it would not be appropriate to use the goodness-of-fit test on this specific internship activity and/or benefit, as 28 cells (80\%) have expected cell counts of less than five (see Table 6).

The Kruskal-Wallis is a non-parametric test requiring only ordinal-level (ranked) data. No assumptions related to the shape of populations are required. For the Kuskall-Wallis to be applied, the samples selected from the group must be independent (Lind, Marchal \& Mason, 2002).

After applying a Kruskal-Wallis test of significance the relationship was no longer found to be significant at the $p<.05$ level, $\left[\mathrm{X}^{2}\right.$ (4, $\mathrm{N}=128)=6.55, p=.16]$. 
Table 6. Chi-square Test of Association between Airlines and Responses to the Internship Activity "Guaranteed Job Interview"

\begin{tabular}{|c|c|c|c|c|c|c|c|c|c|}
\hline Level & Count & American & $\begin{array}{l}\text { Chicago } \\
\text { Express }\end{array}$ & Delta & Northwest & TWA & United & UPS & Total \\
\hline & Observed & 2 & 0 & 2 & 0 & 3 & 2 & 0 & 9 \\
\hline \multirow[t]{3}{*}{ No Value } & Expected & .9 & .4 & 1.0 & .1 & 1.0 & 5.5 & .1 & 9.0 \\
\hline & \% within Airline & $15.4 \%$ & $.0 \%$ & $14.3 \%$ & $.0 \%$ & $21.4 \%$ & $2.6 \%$ & $.0 \%$ & $7.0 \%$ \\
\hline & Observed & 1 & 0 & 0 & 0 & 0 & 0 & 0 & 1 \\
\hline \multirow[t]{3}{*}{$\begin{array}{l}\text { Little } \\
\text { Value }\end{array}$} & Expected & .1 & .0 & .1 & .0 & .1 & .6 & .0 & 1.0 \\
\hline & \% within Airline & $7.7 \%$ & $.0 \%$ & $.0 \%$ & $.0 \%$ & $.0 \%$ & $.0 \%$ & $.0 \%$ & $.8 \%$ \\
\hline & Observed & 2 & 0 & 2 & 0 & 4 & 2 & 0 & 10 \\
\hline \multirow[t]{3}{*}{ Neutral } & Expected & 1.0 & .5 & 1.1 & .1 & 1.1 & 6.1 & .2 & 10.0 \\
\hline & \% within Airline & $15.4 \%$ & $.0 \%$ & $14.3 \%$ & $.0 \%$ & $28.6 \%$ & $2.6 \%$ & $.0 \%$ & $7.8 \%$ \\
\hline & Observed & 1 & 0 & 2 & 1 & 2 & 10 & 1 & 17 \\
\hline \multirow[t]{3}{*}{ Valuable } & Expected & 1.7 & .8 & 1.9 & .1 & 1.9 & 10.4 & .3 & 17.0 \\
\hline & \% within Airline & $7.7 \%$ & $.0 \%$ & $14.3 \%$ & $100.0 \%$ & $14.3 \%$ & $12.8 \%$ & $50.0 \%$ & $13.3 \%$ \\
\hline & Observed & 7 & 6 & 8 & 0 & 5 & 64 & 1 & 91 \\
\hline \multirow[t]{2}{*}{$\begin{array}{c}\text { Extremely } \\
\text { Valuable }\end{array}$} & Expected & 9.2 & 4.3 & 10.0 & .7 & 10.0 & 55.5 & 1.4 & 91.0 \\
\hline & \% within Airline & $53.8 \%$ & $100.0 \%$ & $57.1 \%$ & $.0 \%$ & $35.7 \%$ & $82.1 \%$ & $50.0 \%$ & $71.1 \%$ \\
\hline Total & Count & 13 & 6 & 14 & 1 & 14 & 78 & 2 & 128 \\
\hline
\end{tabular}

\section{CONCLUSIONS}

Respondents assigned to multiple airlines perceived individual airline flight operations internship activities and/or benefits to be of value in the pursuit of career goals.

\section{Discussion of Collective Findings}

Mean values for internship activities and/or benefits ranged from 4.55 to 3.52. Seven internship activities and/or benefits possessed means of 4.04 or higher. The aggregate mean for the 14 internship activities and/or benefits was 4.06. All internship activities and/or benefits were viewed as possessing some value; however, internship activities and/or benefits that allowed respondents to network with airline personnel, assisted in acquiring future employment, provided access to training facilities and allowed exposure to the operational environment of the airline industry were considered most valuable. "Preferential Hiring with a Regional Airline" did not rank as highly as anticipated by the researcher; however, 61 respondents $(40.7 \%)$ indicated that preferential hiring opportunities with regional airlines were not available during their internship. Of the 89 respondents who did have access to the activity and/or benefit, 51 respondents $(57.3 \%)$ considered it valuable or extremely valuable in the pursuit of their career goals.

"Jumpseat/Observing Member of the Crew Privileges" was identified as the most valuable internship activity and/or benefit $(M=4.55)$ in the pursuit of career goals. During my tenure as department airline flight operations internship coordinator, interns have often remarked on the value they placed on the jumpseat activity. Interns often described the opportunity to view airline flight operations "first hand" as "invaluable". "Opportunity to Observe Executive Meetings" was identified as the least valuable internship activity and/or benefit $(M=$ 3.52 ) in the pursuit of career goals. I speculate that the reason for this lack of perceived value was the role interns were most likely allowed to 
play in these meetings. They may have been allowed to observe the meetings, but not participate in their proceedings.

\section{Most Valuable and Least Valuable Activities and/or Benefits by Airline}

Data that was categorized and analyzed by individual airline indicated that respondents perceived internship activities and/or benefits that allowed them access to training classes/facilities, exposure to the airline operational environment, and assisted in acquiring future employment were considered the most valuable in the pursuit of career goals. Respondents perceived travel opportunities, tours of airline facilities, and the opportunity of observe executive meetings as the least valuable internship activities and/or benefits in the pursuit of career goals.

\section{Statistically Significant Differences Among Airlines}

There were no statistically significant differences $(p<.05)$ in the manner respondents from different airlines perceived the value of airline flight operations internship activities and/or benefits in the pursuit of career goals.

\section{RECOMMENDATIONS}

1. Internship activities and/or benefits whose collective mean equaled or exceeded 4.00 were considered valuable or extremely valuable in the pursuit of career goals. As such, airlines that offer airline flight operations internships should consider providing the following internship activities and/or benefits:

a. Jumpseat/observing member of the crew

b. Opportunities to view airline operations first hand

c. Opportunities to work within the airline

d. Guaranteed job interviews

e. Opportunities to interact and network with airline personnel

f. Access to aircraft simulators

g. Access to aircraft ground schools

h. Interview Preparation/Access to the

\section{i. Hiring Process}

2. Conduct a research study that updates the list of activities and/or benefits offered by major air carriers hosting internships.

3. Conduct a research study that updates the list of activities and/or benefits offered by regional air carriers hosting internships.

Airline flight operations internships expose students to learning experiences that cannot be duplicated in the classroom. As such, it is the responsibility of the collegiate aviation institution and the participating air carrier to ensure that these experiences are meaningful and rewarding. Identifying activities and/or benefits that interns perceive as valuable in the pursuit of their career goals is a start in this direction. 


\section{REFERENCES}

Best, J.W., \& Kahn, J.V. (1993). Research in education ( $7^{\text {th }}$ ed.). Needham Heights, MA: Allyn-Bacon.

Bradley, P. (1997, September). Is the pilot shortage coming? Business and Commercial Aviation. 78-80.

Department of Aviation Management and Flight (AVMAF). (1999). Airline internships offered at Southern Illinois University Carbondale. Carbondale, IL: Author.

Kiteley, G.W. (1997, November). Aviation industry and college partnerships in the United States. Auburn, AL: University Aviation Association.

Lind, D.A., Marchal, W.G., \& Mason, R.D. (2002). Statistical techniques in business and economics (11 ${ }^{\text {th }}$ ed.). New York, NY: McGraw-Hill Irwin.

NewMyer, D. A. (1991)..Status report: An airline-university cooperative pilot career program. Collegiate Aviation Review, 15-22

NewMyer, D.A., Ruiz, J.R., \& Rogers (2000). University flight operations internships with major airlines: Airline perspectives. The Journal of Air Transportation World Wide, 5(2), 111-129 .

Phillips, W. (1996, November). Internships and coops: Collegiate programs that can make your career take off. Flight Training, 43-47.

Ruiz, J.R. (2001). Collegiate aviation internships with U.S. major airlines: A changing climate. Paper presented to the Aviation Management Education and Research Conference. Abstract retrieved August 15, 2001 from http://www.johnmolson.concordia.ca/amerc 